\title{
ANALISIS PROGRAM HUTAN KEMASYARAKATAN (HKm) DI DESA DARA KUNCI KABUPATEN LOMBOK TIMUR PROVINSI NTB ${ }^{1}$
}

Analysis Of CommunityForest Program (HKm) In Dara Kunci Village East Lombok District

West Nusa Tenggara Province

\author{
Oleh: \\ Mey Susanti $\mathrm{AS}^{1)}$, Kismartini ${ }^{2)}$, Hartuti Purnaweni ${ }^{3)}$ \\ Sekolah Tinggi Ilmu Administrasi Mataram \\ Email: mey.susanti.as77@gmail.com
}

\begin{abstract}
ABSTRAK
Penelitian ini bertujuan untuk (1) menganalisis pelaksanaan program HKm oleh Kelompok HKm Wana Lestari di Desa Dara Kunci, Kabupaten Lombok Timur; (2) mendeskripsikan faktor-faktor pendukung dan penghambat pelaksanaan Program HKm. Metode penelitian menggunakan metode deskriptif kualitatif dengan mengacu pada kesesuaian antara proses pelaksanaan Program HKm di Desa Dara Kunci Kabupaten Lombok Timur Provinsi NTB dengan PERDA Provinsi NTB Nomor 6 Tahun 2004 tentang Pedoman Penyelenggaraan Hutan Kemasyarakatan di Provinsi NTB, dan untuk menganalisis faktor-faktor pendukung dan penghambatnya mengacu pada teori Model Kesesuaian David C. Korten. Lokasi penelitian di Desa Dara Kunci, Kabupaten Lombok Timur Provinsi NTB, menggunakan teknik pengumpulan data dengan wawancara mendalam, studi pustaka dan observasi. Hasil penelitian menunjukkan bahwa terdapat ketidaksesuaian dengan PERDA Provinsi NTB Nomor 6 Tahun 2004, yang disebabkan oleh: (1) Motivasi dari masyarakat penerima manfaat untuk mengelola kawasan HKm; (2) Belum ada evaluasi program dari pihak pemerintah; (3) Bibit yang didatangkan tidak tepat musim; (4) Unit pelaksana teknis tidak didukung oleh sumber daya finansial yang memadai; (5) Luas areal kawasan $\mathrm{HKm}$ dan banyaknya kelompok mengakibatkan pendampingan kurang maksimal; (6) Program pemberdayaan terhadap masyarakat yang tidak tepat sasaran; (7) Pengembangan potensi masyarakat tidak optimal. Berdasarkan hasil penelitian, dirumuskan saran yaitu: (1) Perlunya peningkatan kualitas kerjasama kemitraan dengan berbagai stakeholder baik instansi pemerintah dan swasta sehingga bisa bermanfaat secara maksimal kepada seluruh anggota Kelompok HKm Wana Lestari Desa Dara Kunci (2) Perlunya penyegaran kepada anggota kelompok terkait dengan pola pengelolaan $\mathrm{HKm}$, sehingga memahami kembali aturan tanam, hak dan kewajiban sebagai pengelola kawasan HKm. (3) Perlunya peningkatan kualitas dan kapasitas kelompok melalui pendampingan secara rutin di lapangan karena hal ini dapat mempengaruhi proses berjalan atau tidaknya program, terutama kepada pengurus sehingga roda organisasi kelompok bisa berjalan dengan baik. (4) Untuk pelaksanaan kegiatan-kegiatan rehabilitasi perlu adanya peningkatan kualitas perencanaan sehingga hasilnya bisa maksimal. (5) Perlu adanya peningkatan pelatihan pengolahan hasil dari sumber daya hutan terutama kepada ibuibu Kelompok Wanita Tani dari kelompok HKm ini.
\end{abstract}

Kata Kunci: Analisis, Program, Penyelenggaraan, Hutan Kemasyarakatan (HKm), Berkelanjutan, Kesejahteraan.

Artikel ini telah dipublikasikan pada Jurnal IImiah Tata Sejuta STIA Mataram Volume 4 No. 1 (2018) pada http://ejurnalstiamataram.ac.id/index.php/tatasejuta/article/view/48 


\begin{abstract}
This paper aims to (1) analyze the implementation of Community Forest Program (HKm) byWana Lestari Group in Dara Kunci Village, East Lombok District; (2) to describe the supporting and inhibiting factors of Community Forest Program (HKm) implementation. The research method used qualitative descriptive method with reference to suitability between Community Forest Program $(\mathrm{HKm})$ implementation process in Dara Kunci Village of East Lombok District of NTB (West Nusa Tenggara) Province with Regional Regulation of NTBProvince number 6, 2004 concerning Guidelines for Implementation of Community Forest $(\mathrm{HKm})$ in NTB Province, and to analyze the supporting and inhibiting factors referring to the theory of Conformity Model David C. Korten. The research location in Dara Kunci Village, East Lombok District, NTB Province, uses data collection techniques with in-depth interview, literature study and observation. The result of this research shows that there is inconsistency with Regional Regulation of Province of NTB Number 6, 2004, which is caused by: (1) Motivation from beneficiaries community to manage HKm area; (2) There has been no program evaluation from the government; (3) Seeds that are imported are not seasonally appropriate; (4) The technical implementation unit is not supported by adequate financial resources; (5) Area of $\mathrm{HKm}$ area and number of groups resulted in less maximal assistance; (6) Community empowerment programs that are not properly targeted; (7) Development of community potential is not optimal. Based on the result of this research, it is formulated suggestions: (1) The need to improve the quality of partnership cooperation with various stakeholders both government and private institutions so that it can benefit maximally to all members of HKm Group Wana Lestari Desa Dara Kunci (2) The need for refreshing to group members related to the pattern management of HKm, thus re-understanding the rules of planting, rights and dutyin managing of HKm area. (3) The need to improve the quality and capacity of the group through routine facilitation in the field because this can affect the running program process or not, especially to the board so that the group organization can run well. (4) For the implementation of rehabilitation activities it is necessary to improve the quality of planning so that the result can be maximized. (5) There needs to be an increase of training on the processing of products from forest resources, especially to women farmer group from this HKm group.
\end{abstract}

Keywords: Analysis, Program, Implementation, Community Forest (HKm), Continuous, Welfare.

\section{PENDAHULUAN}

\section{A. LATAR BELAKANG}

Salah satu upaya untuk meningkatkan kesejahteraan masyarakat di sekitar hutan adalah dengan meningkatkan akses masyarakat terhadap hutan dengan memanfaatkan potensinya tanpa merubah fungsi kawasan hutan. Dalam hal ini, upaya tersebut adalah melalui program Hutan Kemasyarakatan (HKm). Hutan Kemasyarakatan (HKm) menjadi salah satu kebijakan yang dikeluarkan oleh Kementerian Kehutanan untuk menekan laju deforestasi di Indonesia dengan melibatkan masyarakat, di samping Hutan Desa dan Hutan Tanam Rakyat. Banyak pihak yang memandang kebijakan ini sebagai pengakuan Negara terhadap 
pengelolaan hutan oleh rakyat yang selama ini terabaikan, namun mampu menjaga kelestarian alam dan memberikan kesejahteraan bagi masyarakat. Bagi masyarakat, hutan tidak hanya memiliki makna ekologis tetapi juga sosial, budaya dan ekonomi.

Hutan Kemasyarakatan ( $\mathrm{HKm})$ hanya diberlakukan di kawasan hutan lindung dan hutan produksi yang tidak dibebani hak atau izin dalam pemanfaatan hasil hutan di mana kawasan tersebut menjadi sumber mata pencaharian masyarakat setempat. Izin Usaha Pemanfaatan Pengelolaan HKm (IUPHKm) diberikan untuk jangka waktu 35 tahun dan diperpanjang sesuai dengan hasil evaluasi setiap 5 tahun. Program Hutan Kemasyarakatan $(\mathrm{HKm})$ ini adalah upaya untuk mengentaskan kemiskinan masyarakat namun realitanya masih menyisakan permasalahan dan konflik, baik konflik horizontal maupun konflik vertikal.

Beberapa permasalahan yang dihadapi pada Program Hutan Kemasyarakatan dalam upaya mengentaskan kemiskinan masyarakat diantaranya adalah kebijakan yang tidak konsisten mengakibatkan kerusakan sumber daya hutan semakin hebat, tumpang tindihnya hak dan kegiatan pemanfaatan sumber daya hutan dan terhambatnya upaya pengembangan ekonomi masyarakat; Rendahnya pendapatan masyarakat yang diakibatkan oleh sumber daya hutan cenderung semakin rusak akibat eksploitasi hutan, sehingga menyebabkan masyarakat semakin sulit mengembangkan potensi diri. Akibatnya standar minimal kebutuhan masyarakat sulit terpenuhi, dan pada akhirnya masyarakat kurang dapat berpartisipasi dalam program pembangunan; Kurangnya lapangan kerja yang tersedia menyebabkan masyarakat semakin tergantung pada sumber daya hutan dan masyarakat cenderung melegalkan segala cara dalam mengeksploitasi sumber daya hutan, yang mengakibatkan banyak pengangguran maupun setengah penganggur sehingga produktivitas masyarakat rendah dan mudah dihasut untuk melakukan kegiatan yang negatif; Kurangnya peran dan sinergitas di antara para pihak (stakeholder), baik sinergitas antar sektor maupun antar tingkat pemerintahan mengakibatkan terjadinya tumpang tindih dan/atau kesenjangan kegiatan sehingga tidak efektif dan efisien; Terjadinya gap antara kebijakan dan pelaksanaan (Retnowathi, 2015).

Realitas kegiatan pengelolaan hutan yang selama ini lebih berorientasi pada pertumbuhan ekonomi telah menyebabkan termarginalisasinya masyarakat yang hidup di dalam dan sekitar hutan. Akibatnya, timbul ketidakadilan ekonomi yang berdampak pada kesenjangan kesejahteraan antar masyarakat, khususnya antar masyarakat yang memiliki akses terhadap manfaat hutan (pengusaha hutan, dan elit lokal) dengan masyarakat kebanyakan yang memiliki keterbatasan akses terhadap manfaat hutan.

Rendahnya kapasitas sumber daya manusia (pendidikan, sosial ekonomi, dan informasi) mengakibatkan semakin terbatasnya akses masyarakat di dalam dan di sekitar hutan terhadap manfaat ekonomi hutan. Untuk meningkatkan kapasitas sumber daya manusia tersebut, masyarakat terlebih dahulu harus dientaskan dari kemiskinan agar memperoleh akses terhadap pendidikan dan informasi.

Secara ekonomi, peningkatan pendapatan masyarakat melalui program hutan kemasyarakatan, memang memungkinkan masyarakat melestarikan sumber daya hutan, namun hal tersebut hanya mungkin dan akan berlangsung secara konsisten, bilamana pendapatan masyarakat sudah meningkat sampai di atas garis kemiskinan subsistence level atau dengan kata lain keseimbangan ekonomi masyarakat sudah berada di atas tingkat keseimbangan dasar (basic equilibrium). Tapi bila keseimbangan ekonominya masih di bawah 
keseimbangan dasar, maka masyarakat akan berusaha mencari sumber pencaharian lain meskipun dengan upah yang lebih rendah atau resiko yang tinggi termasuk mengeksploitasi sumber daya hutan. Dari sudut pandang lain, kerusakan sumber daya hutan juga dapat disebabkan oleh perilaku ekonomi masyarakat yang kurang bertanggung jawab. Hal ini juga sangat tergantung pada pengetahuan, kesempatan, karakter individu, orientasi nilai, dan kesadaran masyarakat itu sendiri. Sehingga dengan semakin terbukanya akses mereka terhadap sumber daya hutan maka justru mempermudah mereka mengeksplotasi sumber daya hutan tersebut.

Atas dasar ini pemerintah mengeluarkan Undang-Undang Pokok Kehutanan yang baru yaitu, UndangUndang Nomor 41 Tahun 1999 tentang Kehutanan. Undang-Undang ini diharapkan akan dapat memecahkan permasalahan yang selama ini terjadi, yaitu keamanan hutan dan kesejahteraan masyarakat sekitar hutan. Undang-Undang ini merupakan paradigma baru dibidang kehutanan di mana di dalamnya banyak memberikan kesempatan kepada masyarakat untuk ikut mengelola dan memelihara hutan sehingga diharapkan masyarakat nantinya akan lebih terberdaya, khususnya dalam pengelolaan hutan.

Kebijakan pembangunan kehutanan telah mengalami perkembangan sejalan dengan adanya Undang-Undang Nomor 32 Tahun 2004 tentang Otonomi Daerah, yang semula pemerintahan lebih bersifat sentralistik menjadi bersifat desentralistik. Adanya desentralisasi di bidang kehutanan memberikan peluang yang lebih besar bagi masyarakat untuk berpartisipasi dalam kegiatan pengelolaan hutan dan diharapkan hutan dapat memberikan kesejahteraan bagi masyarakat di sekitarnya.

Secara nasional, pelaksanaan konsep $\mathrm{HKm}$ telah dikembangkan pada 22 Provinsi dengan luas keseluruhan sekitar
448.217 Ha yang terdiri dari areal Usulan Penetapan Wilayah HKm (162.112,91 Ha), areal Pembangunan HKm (208.327 $\mathrm{Ha})$, areal Kerja Social Forestry (55.420 $\mathrm{Ha})$ dan areal yang diberi ijin sementara (62.357 Ha). Total kelompok masyarakat yang terlibat pada kegiatan $\mathrm{HKm}$ adalah 519 kelompok (Media DAS, 2007).

Salah satu provinsi yang telah melaksanakan HKm adalah Provinsi Nusa Tenggara Barat (NTB). Beberapa praktek $\mathrm{HKm}$ yang ada di NTB antara lain HKm yang dikelola oleh Perum Perhutani sebagai lanjutan kegiatan HTI di Sumbawa, HKm Dinas Kehutanan Provinsi NTB, HKm Kelompok Mitra Pengaman Hutan (KMPH) Sesaot, Lombok Barat, yang difasilitasi oleh LP3ES NTB, HKm di kawasan hutan Batukliang, Lombok Tengah yang difasilitasi oleh Dinas Kehutanan Kabupaten Lombok Tengah dan Dinas Kehutanan Provinsi NTB, serta pengembangan $\mathrm{HKm}$ di Provinsi NTB bantuan OECF (Overseas Economic Cooperation Fund) di Lombok Timur dan Lombok Barat (Departemen Kehutanan, 1995).

Permasalahan umum adalah pengelolaan hutan yang belum optimal dan masih tingginya kemiskinan masyarakat di sekitar kawasan hutan. Laporan Keterangan Pertanggungjawaban Gubernur NTB Tahun 2016, menyatakan bahwa tingkat kemiskinan penduduk NTB tahun 2012 mencapai $18,63 \%$ dan tahun 2016 menjadi $16,48 \%$, berarti setiap satu tahun di NTB ada penurunan angka kemiskinan rata-rata sebesar $01,08 \%$, namun diperkirakan penduduk miskin tersebut banyak tersebar di sekitar kawasan hutan selain di wilayah pesisir dan perkotaaan.

Kawasan hutan di Pulau Lombok tidak terlepas dari keberadaan kawasan Gunung Rinjani (125.000 ha), di mana sebagian besar berbatasan langsung dengan wilayah Kabupaten Lombok Timur (60.329,67 ha). Dari 20 kecamatan yang ada di Kabupaten Lombok Timur, 50\% di antaranya berada 
di sekitar dan berinteraksi langsung dengan kawasan hutan, yaitu Kecamatan Sambelia, Sembalun, Suela, Pringgabaya, Wanasaba, Aikmel, Pringgasela, Sikur, Montong Gading dan Jerowaru. Di 10 kecamatan yang didiami oleh 544.673 jiwa (197.516 KK) tersebut terdapat 93.464 KK prasejahtera (Kecamatan Sambelia Dalam Angka 2016, BPS Kab. Lombok Timur). Berdasarkan data tersebut, tingkat kemiskinan masyarakat tergolong masih cukup tinggi (hampir $50 \%$ ). Kondisi ini berbanding terbalik, di mana potensi sumber daya alam yang ada di kawasan hutan tersebut sangat kaya namun masyarakatnya masih hidup dalam kemiskinan.

\section{B. TUJUAN}

Penelitian ini bertujuan menganalisis pelaksanaan Program Hutan Kemasyarakatan (HKm) oleh kelompok HKm Wana Lestari di Desa Dara Kunci, Kecamatan Sambelia, Kabupaten Lombok Timur serta mendeskripsikan faktor-faktor pendukung dan penghambat pelaksanaan program HKm di Desa Dara Kunci, Kecamatan Sambelia, Kabupaten Lombok Timur.

\section{TEORI}

\section{Implementasi Kebijakan}

Implementasi kebijakan menurut Riant Nugroho (2015: 657) pada prinsipnya adalah cara agar sebuah kebijakan dapat mencapai tujuannya, melalui dua pilihan langkah yaitu langsung mengimplementasikan dalam bentuk program-program atau melalui formulasi kebijakan derivate atau turunan dari kebijakan tersebut.

Kebijakan publik dalam bentuk Undang-Undang atau Perda adalah jenis kebijakan publik yang memerlukan kebijakan publik penjelas atau yang sering diistilahkan sebagai peraturan pelaksanaan. Kebijakan publik yang bisa langsung operasional antara lain Keppres,
Inpres, Kepmen, Keputusan Kepala Daerah, Keputusan Kepala Dinas dan lainlain.

Korten (1988) (dalam Akib dan Tarigan 2000: 21) mengajukan suatu model implementasi program yakni menggunakan pendekatan proses pembelajaran yang lebih dikenal dengan model kesesuaian implementasi program, seperti dalam gambar berikut:

\section{Model Kesesuaian Implementasi Program dari David C. Korten (1988)}

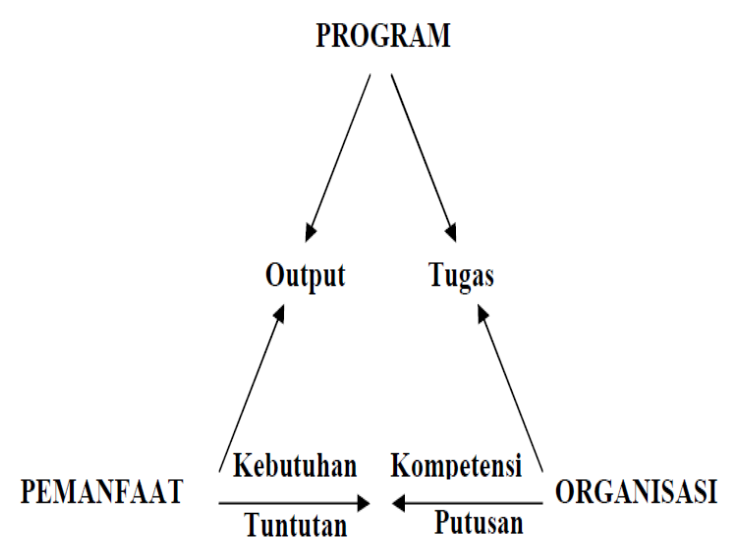

Sumber: Akib dan Tarigan (2000: 12).

Korten menggambarkan bahwa model ini berintikan tiga elemen yang ada dalam pelaksanaan program yaitu program itu sendiri, pelaksanaan program, dan kelompok sasaran program. Korten menyatakan bahwa suatu program akan berhasil dilaksanakan jika terdapat kesesuaian dari tiga unsur implementasi program. Pertama, kesesuaian antara program dengan pemanfaat, yaitu kesesuaian antara apa yang ditawarkan oleh program dengan apa yang dibutuhkan oleh kelompok sasaran (pemanfaat). Kedua, kesesuaian antara program dengan organisasi pelaksana, yaitu kesesuaian antara tugas yang disyaratkan oleh program dengan kemampuan organisasi pelaksana. Ketiga, kesesuaian antara kelompok pemanfaat dengan organisasi pelaksana, yaitu kesesuaian antara syarat yang diputuskan organisasi untuk dapat 
memperoleh output program dengan apa yang dapat dilakukan oleh kelompok sasaran program.

Berdasarkan pola yang dikembangkan Korten, dapat dipahami bahwa kinerja program tidak akan berhasil sesuai dengan apa yang diharapkan kalau tidak terdapat kesesuaian antara tiga unsur implementasi kebijakan. Hal ini disebabkan apabila output program tidak sesuai dengan kebutuhan kelompok sasaran, jelas output tidak dapat dimanfaatkan. Jika organisasi pelaksana program tidak memiliki kemampuan melaksanakan tugas yang disyaratkan oleh program, maka organisasinya tidak dapat menyampaikan output program dengan tepat. Atau, jika syarat yang ditetapkan organisasi pelaksana program tidak dapat dipenuhi oleh kelompok sasaran, maka kelompok sasaran tidak mendapatkan output program. Oleh karena itu, kesesuaian antara tiga unsur implementasi kebijakan mutlak diperlukan agar program berjalan sesuai dengan rencana yang telah dibuat.

\section{Hutan Kemasyarakatan (HKm)}

Hutan kemasyarakatan (HKm), adalah Hutan Negara dengan sistem pengelolaan hutan yang bertujuan untuk memberdayakan masyarakat (meningkatkan nilai ekonomi, nilai budaya, memberikan manfaat benefit kepada masyarakat pengelola, dan masyarakat setempat), tanpa mengganggu fungsi pokoknya (meningkatkan fungsi hutan dan fungsi kawasan, pemanfaaatan jasa lingkungan, pemanfaatan hasil hutan kayu, pemanfaatan hasil hutan bukan kayu dengan tetap menjaga fungsi kawasan hutan).

\section{METODE PENELITIAN}

Penelitian ini termasuk dalam penelitian kualitatif yang bersifat deskriptif dengan menggunakan pendekatan studi kasus. Usaha-usaha untuk menemukan informan dalam penelitian ini dilakukan dengan menggunakan teknik purposive. Pemilihan informan merupakan orang-orang yang benar mengetahui permasalahan serta terpercaya dalam hal ini pada lingkup pemerintahan Provinsi NTB seperti Dinas Lingkungan Hidup dan Kehutanan, UPT KPH Rinjani Timur dan untuk turun di masyarakat dalam memperoleh informasi, dengan penentuan awal informan adalah Ketua Kelompok HKm Wana Lestari dan para anggota Kelompok HKm tersebut serta para anggota Kelompok Wanita Tani Wana Lestari.

Penetapan lokasi penelitian dilakukan berdasarkan penelusuran pustaka mengenai PERDA Provinsi NTB Nomor 6 Tahun 2004 tentang Penyelenggaraan Hutan Kemasyarakatan. Lokasi ini sengaja diambil dengan beberapa pertimbangan di mana Desa Dara Kunci merupakan salah satu dari tiga lokasi areal HKm di Pulau Lombok Provinsi NTB, akan tetapi wilayah di Desa Dara Kunci kerap dilanda bencana banjir bandang dan kekeringan saat musim kemarau, selain itu untuk mengetahui sejauhmana penyelenggaraan hutan kemasyarakatan (HKm) untuk mewujudkan keberdayaan dan kesejahteraan masyarakat kawasan hutan selaku pengelola Hutan Kemasyarakatan $(\mathrm{HKm})$, dan diharapkan data serta temuan yang didapat berguna dalam pemecahan permasalahan yang terjadi dalam Program Hutan Kemasyarakatan (HKm) sehingga dapat diimplementasikan dengan lebih baik.

Jenis data yang digunakan adalah data yang berbentuk teks dan data yang berbentuk kata-kata, seperti yang terdapat dalam Lofland dan Lofland (1984: 47) dalam buku Moleong (2016: 157), bahwa sumber data utama dalam penelitian kualitatif ialah kata-kata, dan tindakan, selebihnya adalah data tambahan seperti dokumen dan lain-lain. Sumber data yang digunakan terdiri dari data primer yang berkaitan langsung dengan objek penelitianyang diperoleh dari wawancara dengan informan dan pihak-pihak lain 
yang berhubungan dengan masalah yang sedang diteliti, dan data sekunder mendapatkan informasi atau keterangan dari objek yang diteliti, yang berupa laporan-laporan, dokumen-dokumen atau data-data dan informasi dari sumbersumber lain yang sudah diolah seperti hasil penelitian dan publikasi lainnya seperti koran, newsletter, dan lain-lain yang berhubungan dengan masalah yang sedang diteliti.

Teknik analisis data di lapangan menggunakan model Miles dan Huberman dalam Saldana (2014: 31-33) yang terdiri dari Condensation Data, Display Data, dan Conclusion Drawing/Verifications. Data yang sudah dikumpulkan, dianalisis dan diinterpretasikan melalui reduksi data yang telah dipilah, disajikan, kemudian ditarik kesimpulan atas jawaban-jawaban yang diberikan oleh informan.

Uji keabsahan data dalam penelitian ini menggunakan triangulasi sumber dan triangulasi teknik (Sugiyono 2015: 273). Triangulasi sumber dilakukan dengan cara melakukan cek data yang telah diperoleh melalui beberapa sumber, sedangkan triangulasi teknik dilakukan dengan cara melakukan cek data kepada sumber yang sama dengan teknik yang berbeda. Pengecekan dilakukan menggunakan teknik wawancara, observasi dan dokumentasi.

\section{PEMBAHASAN}

\section{A. GAMBARAN UMUM}

Desa Dara Kunci merupakan salah satu desa definitif dari 11 desa yang berada diwilayah Kecamatan Sambelia Kabupaten Lombok Timur dengan luas wilayah $35.16 .10 \mathrm{Km}^{2}$, dengan luas 3.52 $\mathrm{km} 2$ dari seluruh wilayah Kecamatan Sambelia, dengan topografi berada pada dataran sedang. Dengan topografi ini Desa Dara Kunci ada pada ketinggian 40 mdpl. Desa Dara Kunci yang merupakan desa di dekat pantai dan hutan dipengaruhi oleh 2 musim yaitu musim kemarau dan musim hujan dengan curah hujan sebanyak $1.131,6 \mathrm{~mm} /$ tahun dengan suhu rata-rata $34^{\circ} \mathrm{C}$.

Pada dasarnya kondisi kawasan hutan produksi di KPH Rinjani Timur berada pada kondisi yang kurang baik (agak kritis), tegakan yang ada merupakan hasil kegiatan reboisasi yang dilaksanakan pada tahun-tahun sebelumnya baik berupa Program Gerhan, Hutan Cadangan Pangan, HKm, PHTUL, JIFPRO serta beberapa kegiatan reboisasi lainnya dalam skala kecil seperti pembangunan demplot tanaman.

\section{B. HASIL PENELITIAN}

Pelaksanaan Penyelenggaraan Program Hutan Kemasyarakatan (HKm) Oleh Kelompok HKm Wana Lestari di Desa Dara Kunci Kecamatan Sambelia Kabupaten Lombok Timur Provinsi NTB

Implementasi Program Hutan Kemasyarakatan $(\mathrm{HKm})$ yang diperkuat dengan regulasi yaitu Peraturan daerah Nomor 6 Tahun 2004 tentang Pedoman Penyelenggaraan Hutan Kemasyarakatan di Provinsi NTB sangat bemanfaat bagi ekologi. Hal ini bisa tercapai apabila masyarakat selaku penerima manfaat $\mathrm{HKm}$ bisa melaksanakan kelola kawasan sebagai tempat ekologi dan melaksanakan fungsi hutan baik fungsi tata air/hidrologi, konservasi dan perubahan iklim. Apabila semua ini berjalan maka manfaat ekologi bisa tercapai, karena perlu diketahui bahwa kondisi/proporsi tanaman yang ada di lahan HKm tersebut banyak yang tidak sesuai. Jika mengacu pada aturan porsi tanaman maka tanaman keras sebanyak $60 \%$ dan $40 \%$ lainnya adalah tanaman pangan. Akan tetapi pada prakteknya yang terjadi malah sebaliknya.

Pelaksanaan Hutan Kemasyarakatan khususnya di Desa Dara Kunci sangat berdampak bagi peningkatan ekonomi anggota kelompok. Hal ini didapatkan dari hasil tanaman MPTS (Multi Purposes Tree 
Species) seperti asam, jambu mente, srikaya dan tanaman palawija/tumpang sari. Dari kondisi awal di mana kehidupan anggota kelompok penerima manfaat hanya untuk hidup sehari-hari, namun saat ini mereka sudah mampu menyekolahkan anak-anak mereka sampai ke tingkat pendidikan perguruan tinggi.

Dari hasil wawancara terkait dengan manfaat sosial-budaya dari program $\mathrm{HKm}$, para informan sepakat menyatakan bahwa $\mathrm{HKm}$ sangat besar pengaruhnya dalam penguatan sosial-budaya masyarakat terutama kepada masyarakat penerima manfaat sebagai bentuk terciptanya kearifan lokal. Seperti sesama anggota sering bergotong-royong baik di dalam kawasan dan yang sering adalah di lingkungan masyarakat dalam berbagai acara contohnya acara pernikahan, zikir, maupun kematian.

Pemerintah Provinsi Nusa Tenggara Barat, dalam hal ini Dinas Lingkungan Hidup dan Kehutanan Provinsi Nusa Tenggara Barat, menyiapkan masyarakat Desa Dara Kunci sesuai dengan program hutan kemasyarakatan untuk melaksanakan pelatihan. Penyiapan masyarakat untuk ikut dalam kegiatan $\mathrm{HKm}$ dilakukan untuk menyiapkan kemampuan, kemauan dan rasa tanggung jawab masyarakat dalam mengelola $\mathrm{HKm}$, sebelum diterbitkan izin. Upaya yang dilakukan dalam mentransmisikan kebijakan/aturan HKm sebelum kelompok terbentuk sudah dilakukan oleh Dinas Lingkungan Hidup dan Kehutanan Provinsi Nusa Tenggara Barat bekerjasama dengan LSM pendamping. Berbagai jenis pelatihan dilakukan dalam penyiapan kemampuan anggota kelompok HKm Wana Lestari, misalnya pelatihan pengelolaan $\mathrm{HKm}$, pelatihan pembibitan, pelatihan admnistrasi kelompok dan pelatihan pengolahan pasca panen. Kendalanya adalah para peserta yang mengikuti pelatihan ini kurang mampu menstransmisikan kepada anggota yang lain sehingga pemahaman mereka tidak sama satu dengan lainnya. Selain itu pelatihan ini juga tidak rutin dilakukan sehingga sangat sulit untuk merubah perilaku atau menambah kemampuan kelompok tersebut dalam mewujudkan "Hutan Lestari Rakyat Sejahtera".

\section{Faktor-faktor Pendukung dan Penghambat Pelaksanaan Program Hutan Kemasyarakatan (HKm)}

a. Kesesuaian antara Hasil Program dengan Kebutuhan Pemanfaat

Banyak ditemukan fakta bahwa motivasi dari masyarakat penerima manfaat dalam hal mengelola kawasan $\mathrm{HKm}$, dimana mereka hanya ingin mendapatkan lahan untuk peningkatan hidup. Belum adanya evaluasi program dari pihak pemerintah. Terkait dengan pengkayaan tanaman untuk areal $\mathrm{HKm}$, bibit yang diberikan didatangkan saat menjelang musim kemarau, sehingga ketika ditanam hanya sedikit yang berhasil hidup.

b. Kesesuaian Pelaksanaan Program dengan Kemampuan Organisasi Pelaksana

Sumber daya manusia dalam hal ini unit pelaksana teknis untuk menjalankan program ini tidak didukung oleh sumber daya finansial yang memadai sehingga secara tidak langsung akan berpengaruh terhadap motivasi organisasi pelaksana. Luasnya areal kawasan $\mathrm{HKm}$ dan banyaknya kelompok HKm mengakibatkan pendampingan dari organisasi pelaksana kurang maksimal dilakukan. Pendampingan yang dibutuhkan oleh pemanfaat juga tidak rutin dilakukan.

c. Kesesuaian antara Kelompok Pemanfaat dengan Organisasi Pelaksana Program pemberdayaan terhadap masyarakat yang tidak tepat sasaran akan mengakibatkan pemborosan dana, waktu dan tenaga. Selain itu pengembangan potensi masyarakat menjadi tidak optimal dan masyarakat semakin tidak berdaya dalam pemanfaatan sumber daya hutan. 
Keberadaan Dinas Lingkungan Hidup dan Kehutanan memungkinkan identifikasi keberadaan dan kebutuhan masyarakat terhadap manfaat sumberdaya hutan dengan lebih jelas dan cermat, sehingga proses-proses pengakuan hak, izin maupun kolaborasi menjadi lebih mungkin dilakukan.

\section{PENUTUP}

\section{A. KESIMPULAN}

1. Pelaksanaan penyelenggaraan Program $\mathrm{HKm}$ oleh Kelompok HKm Wana Lestari di Desa Dara Kunci Kecamatan Sambelia, Kabupaten Lombok Timur, Provinsi NTB:

a. Adanya perbedaan pemahaman masyarakat tentang Program HKm untuk memaksimalkan manfaat ekonomi. Pemahaman tersebut diwujudkan melalui pola tanam dengan memilih jenis-jenis tanaman yang dapat berproduksi dalam jangka pendek dan kontinyu (jenis tanaman musiman) dan tanaman yang berproduksi secara kontinyu dan bernilai ekonomi tinggi (jenis tanaman tahunan). Dari jenis tanaman yang direkomendasikan jika dianggap tidak menguntungkan masyarakat tidak melakukan penanaman, namun jika dianggap memberikan manfaat, masyarakat cenderung akan menanam tanaman yang direkomendasikan meskipun tidak sesuai dengan komposisi yang disepakati. Dalam mencapai manfaat sosial-budaya terlihat dalam pengelolaan dan pemanfaatan sumber daya hutan untuk kehidupan sehari-hari.

b. Dari berbagai jenis pelatihan yang telah dilakukan kendala yang ada adalah para peserta pelatihan kurang mampu mentransmisikan kepada anggota lain hasil dari pelatihannya sehingga pemahaman mereka berbeda satu dengan lainnya. Hal ini dikarenakan rendahnya tingkat pendidikan masyarakat menyebabkan kurangnya informasi mengenai potensi sumber daya sekitarnya.

c. Untuk rehabilitasi dan pemeliharaan hutan, hal ini sudah dijalankan setiap tahunnya oleh kelompok penerima manfaat, namun hasilnya belum maksimal mengingat perencanaan dari instansi pemerintah atau pihak yang mendistribusikan bibit seringkali tidak tepat waktu atau tidak sesuai dengan kondisi musim yang sedang berjalan.

d. Tingginya ketergantungan masyarakat terhadap program pemerintah dan pihak pendamping/LSM berujung pada rendahnya inisiatif dan inovasi masyarakat dalam pengelolaan hutan, terlihat dalam hal pengkayaan tanaman atau pembibitan, masyarakat cenderung menunggu tanpa berinisiatif, sehingga masyarakat menjadi pasif dan tidak mandiri. Selain itu, hal ini berakibat pada lemahnya aspirasi masyarakat terhadap pengelolaan hutan.

2. Faktor-faktor pendukung dan penghambat Pelaksanaan Program HKm di Desa Dara Kunci Kecamatan Sambelia Kabupaten Lombok Timur Provinsi NTB:

a. Dari sisi penerima manfaat program $\mathrm{HKm}$ diketahui bahwa tingkat pertumbuhan dan jumlah penduduk yang semakin padat dan diikuti dengan semakin sempitnya lahan pertanian, menyebabkan sumber daya hutan menjadi alternatif penunjang ekonomi rumah tangga untuk kebutuhan jangka pendek. Kontribusi sumber daya hutan terhadap aspek ekonomi masyarakat di sekitar 
hutan sangat tinggi mengakibatkan eksploitasi cukup berlebihan jika tidak dibina dan didampingi secara intensif oleh pelaksana program dalam hal ini adalah Dinas Lingkungan Hidup dan Kehutanan Provinsi NTB dan UPT KPH Rinjani Timur.

b. Dari pihak implementor dalam hal ini dilaksanakan oleh Dinas Lingkungan Hidup dan Kehutanan Provinsi NTB di tingkat provinsi dan UPT KPH Rinjani Timur di tingkat kabupaten, untuk menjalankan program ini telah menyiapkan sumber daya manusia akan tetapi tidak didukung oleh sumber daya finansial yang memadai sehingga secara tidak langsung akan berpengaruh terhadap motivasi organisasi pelaksana. Selain itu, fasilitasi Program HKm dilakukan oleh LSM dengan bantuan lembaga pendonor. Kebijakan dari pemerintah yang sering berubahubah dan tumpang tindih juga mempengaruhi keberhasilan Program HKm. Kurangnya peran dan sinergitas diantara para pihak (stakeholder), baik di tingkat pusat dan daerah mengakibatkan terjadinya kesenjangan kegiatan, sehingga program menjadi tidak efektif dan efisien.

c. Dari Program HKm sendiri meski telah terjalin kesesuaian baik terkait dengan konsep maupun implementasi dilapangan. Namun yang dihadapi saat ini adalah Dinas Lingkungan Hidup dan Kehutanan kabupaten sudah tidak ada, yang ada hanya ditingkat Provinsi, namun sebagai unit pelaksana teknis di tingkat kabupaten sudah ada, dalam hal ini UPT KPH Rinjani Timur, yang menangani wilayah Kabupaten Lombok Timur yang dapat memfasilitasi.

\section{B. SARAN}

1. Perlunya peningkatan kualitas kerjasama kemitraan dengan berbagai stakeholder baik instansi pemerintah dan swasta sehingga bisa bermanfaat secara maksimal kepada seluruh anggota Kelompok HKm Wana Lestari Desa Dara Kunci.

2. Perlunya penyegaran kepada anggota kelompok terkait dengan pola pengelolaan HKm, sehingga memahami kembali aturan tanam, hak dan kewajiban sebagai pengelola kawasan HKm.

3. Perlunya peningkatan kualitas dan kapasitas kelompok melalui pendampingan secara rutin di lapangan karena hal ini dapat mempengaruhi proses berjalan atau tidaknya program, terutama kepada pengurus sehingga roda organisasi kelompok bisa berjalan dengan baik.

4. Untuk pelaksanaan kegiatan-kegiatan rehabilitasi perlu adanya peningkatan kualitas perencanaan sehingga hasilnya bisa maksimal.

5. Perlu adanya peningkatan pelatihan pengolahan hasil dari sumber daya hutan terutama kepada ibu-ibu Kelompok Wanita Tani dari kelompok $\mathrm{HKm}$ ini.

\section{DAFTAR PUSTAKA}

Akib, Haedar., Tarigan, Antonius., 2000, Artikulasi Konsep Implementasi Kebijakan: Perspektif, Model dan Kriteria Pengukurannya.

Departemen Kehutanan, 1995, Manual Kehutanan. Kopkarhutan. Jakarta.

Kecamatan Sambelia Dalam Angka 2016, Badan Pusat Statistik Kabupaten Lombok Timur Provinsi NTB.

Media DAS, 2007, Perubahan Paradigma Pembangunan Kehutanan: Kerjasama Pusat dan Daerah Sangat Diperlukan. Edisi 07/Tahun I/Desember 2007. Jakarta. 
Moleong, Lexy, 2016, Metodologi Penelitian Kualitatif, Rosda Karya, Bandung.

Nugroho, Riant, 2014, Public Policy, Elex Media Komputindo, Jakarta.

Retnowathi, Renny, 2015, HKm Menjadi

Solusi Permasalahan Kehutanan, Diakses dari:

hutankitarenny.blogspot.co.id/201

5/01/hkm-menjadi-solusi-

permasalahan.html.

Saldana, 2014, Qualitative Data Analysis:

A Methods Sources Book, 3rd

Edition. United States of America:

SAGE Publications, Inc.

Sugiyono, 2015, Metode Penelitian Kuantitatif Kualitatif dan R\&D, Alfabeta, Bandung. 